\title{
GLOUCESTER'S INWARDNESS AND MATERNAL ANXIETY IN KING LEAR
}

\author{
Interioridade e Fantasias Maternas em King Lear \\ Interioridad y Fantasías Maternas en El Rey Lear
}

\section{Carlos Roberto Ludwig ${ }^{* 1}$}

${ }^{1}$ Grupo de Pesquisa Literatura, Subjetividade e Pensamento, Curso de Letras - Inglês e Programa de PósGraduação em Letras, Universidade Federal do Tocantins, Porto Nacional, Brasil.

*Correspondência: Núcleo Interdisciplinar de Estudos Literários, Universidade Federal do Tocantins, Jardim dos Ipês, Rua 03, S/N, Setor Aeroporto, Porto Nacional, Tocantins, Brasil. CEP:77.000-000. e-mail carlosletras@uft.edu.br

\section{RESUMO}

Este ensaio discute as questões de interioridade e angústias maternas na peça King Lear de Shakespeare. Aborda também o conceito de significante, baseado nos pressupostos de Lacan. Primeiramente, apresenta os pressupostos de Lacan sobre o significante e a constituição da subjetividade. Depois disso, discute as angústias maternas partindo do trabalho de Janet Adelman (1992). Adelman estuda fantasias maternas baseadas na psicanálise Freudiana, mas nunca menciona os pressupostos de Lacan. Ela não revela os dispositivos mais profundos na interioridade de Lear que são negados e reprimidos, cujas projeções dirigidas e internas sugerem dimensões e disposições escuras do self interior de Lear. Ela só discute fantasias maternas re-imaginado com suas filhas. Para preencher essa lacuna, discuto e analiso as constelações psíquicas que se revelam nos silêncios, não-ditos e não sequituros de seus discursos, que apontam um conjunto de metáforas projetadas além da fase pré-edipiana, experimentada por Gloucester. Essa experiência não será dirigida somente a sua imagem de Edgar, mas ele projeta sua raiva para outros personagens da peça, como Edmond e suas figuras maternas. A experiência de autoindividuação poderia ser associada a uma cadeia de elementos imagéticos e paranóicos, que apontam para a perda da referencialidade, da totalidade e da centralidade da psique e, conseqüentemente, confunde e re-direciona o locus de suas projeções interiores. Segundo Lacan, o inconsciente é algo puramente lógico, em outras palavras, é algo originado do significante.

Palavras-Chave: Significante; Interioridade; Fantasias Maternas; Rei Lear de Shakespeare.

\section{ABSTRACT}

This essay aims at discussing the issues of inwardness and maternal anxieties in Shakespeare's play King Lear. It also approaches the signifier, based on Lacan's assumptions. It first presents Lacan's assumptions on the signifier and the constitution of subjetivity. After that, it discusses maternal anxieties based on Janet Adelman's work (1992). Adelman studies maternal fantasies based on Freud's psychoanalytic framework, but she never mentions Lacan's assumptions. She does not reveal the deeper devices in Lear's inwardness are denied and repressed, whose driving and inward projections suggest dark dimensions and dispositions of Lear's inner self; she only discusses maternal fantasies re-imagined with his daughters. In order to overcome this gap, I discuss and analyse the psychic constellations which are revealed in the silences, non-said, and non-sequiturs of his speeches, which point out a set of metaphors projected beyond the pre-oedipal phase, experienced by Gloucester. Such experience will not be directed only to his son Edgar image, but he projects his anger to other characters in the play, such as Edmond and his maternal figures. The experience of self individuation could be associated to a chain of imagetic, paranoid elements, which point out the loss of referenciality, wholeness and centrality of the psyche of the self, and consequently confuses him and makes him re-direct the locus of his inward projections. According to Lacan, the unconscious is something purely logic, in other words, it is something originated from the signifier.

Key-words: Signifier; Inwardness; Maternal Fantasies; Shakespeare's King Lear.

\section{RESUMEN}


Este ensayo discute los problemas de la interioridad y la angustia materna en la obra El Rey Lear de Shakespeare. También se analiza el concepto de significante, basado en los supuestos de Lacan. En primer lugar, presenta los supuestos de Lacan sobre el significante y la constitución de la subjetividad. A partir de entonces, discute la angustia materna partindo del trabajo de Janet Adelman (1992). Adelman estudia las fantasías maternas basado en el psicoanálisis freudiano, pero nunca menciona los supuestos de Lacan. Ella no revela los dispositivos más profundos en el interior de Lear que son negados y reprimidos, cuyas proyecciones interires sugieren dimensiones y disposiciones oscuras del sujeto de Lear. Sólo discute las fantasías maternales re-imaginados con sus hijas. Para llenar este vacío, discuto y analizo las constelaciones psíquicas que se revelan en los silencios y no sequituros de sus discursos, que enlazan una serie de metáforas además de la fase de pre-edípica, experimentada por Gloucester. Esta experiencia no sólo se dirige a imagen de su hijo Edgar, pero él proyecta su ira a otros personajes de la obra, como Edmond y sus figuras maternas. La experiencia de auto-individuación podría estar relacionado con una cadena de la imaginería y elementos paranoides relacionadas con la perda de referencial, la totalidad y la centralidad de la psique y por lo tanto confuso y re-dirige el lugar de sus proyecciones interiores. Según Lacan, el inconsciente es puramente lógico, en otras palabras, es algo que se originó a partir significativa.

Descriptores: Significante; Interioridad; Fantasías Maternas; El Rey Lear de Shakespeare.

\section{INTRODUCTION}

This essay debates the issues of inwardness and maternal anxieties in the play King Lear, by William Shakespeare. It also approaches the signifier, based on Lacan's assumptions. It first presents Lacan's assumptions on the signifier and the constitution of subjetivity. After that, it discusses maternal anxieties based on Janet Adelman's work (1992). Adelman studies maternal fantasies based on psychoanalytic framework, but she never mentions Lacan's assumptions. She does not reveal the deeper devices in Lear's inwardness are denied and repressed, whose driving and inward projections suggest dark dimensions and dispositions of the inner self. In order to overcome this gap, I will analyse the psychic constellations which are revealed in the silences, non-said, and non-sequiturs of his speeches, which point out a set of metaphors projected beyond the pre-oedipal phased, experienced by Gloucester. Such experience will not be directed only to his son Edgar image, but he projects his anger to other characters in the play, such as Edmond and his maternal figures. The experience of self individuation could be associated to a chain of imagetic, paranoid elements, which point out the loss of referenciality, wholeness and centrality of the psyche of the self, and consequently confuses him and makes him redirect the locus of his inward projections. According to Lacan, the unconscious is something purely logic, in other words, it is something originated from the signifier.

\section{RESULTS AND DISCUSSION}

\section{Lacan's Signifier and Inwardness}

In the Mirror Stage essay, Lacan starts from the neurological assumption that human beings are born in a foetus form: the newborn cannot coordinate movements, with instinctive or willful intentions, i. e. he cannot walk, nor cannot keep himself in an erect position. He points out that until six months old the baby expresses himself in a set of spasmodic and joyful reaction in its gestures and movements. Thus, the mirror stage is considered by Lacan as an identification process of a particular sort: the mother's presence is perceived as a continuum of the infant's own body, as if the mother were his own self. The only thing it identifies is the blissful joint with the breast of the mother. According to Lacan,

The joyful assumption of the specular image to this being still plunged in the moving impotency and in the dependence of being breast-fed which is the nestling of the human being in this stage of infants shall seem to us to manifest thus, in an 
exemplar situation, the symbolic matrix in which the $[I]$ plunges itself in a primordial form, before being objectified in the dialectics of identification with the other and before the language restitutes himself, in the universal, his function of subject (LACAN, 1998, p. 97).

This is the functional identification of the alienated image of the self - a 'self' which does not make any distinction between himself and the other (mother), not seeing himself - partially - in the other's image, but literally occupying or canibalising the other, which can only be configured through the imago. This alienated imago is a hallucinatory projection - with the whole range of agressive conotations interwoven into the joyful emotions. This alienation constitutes the foetus' identity, the fantasy of the own body unified with the mother's. He only declines with his acknowledgment of the father's presence: her desire turned towards the hushand or another member of the family occupying the symbolic position of the father limits the blissful fusion with the child, signalling to the child that her image is a limitation (a symbolic castration) which splits the blissful dual union. The child depends on the mother imaginary, suggesting this symbolic separation, which instaured the oedipal triangulation - thus overcoming the false image of the totality of the self: the phagocytising process, through which the foetus-baby wishes to occupy entirely the locus of the imago. This mirror stage is more likely a fortress where the self produces barriers to be isolated. This fortress image could be seen as the id image and construction. ${ }^{1}$ However, when the baby first

\footnotetext{
1 'Correlatively, the formation of the $[I]$ symbolizes dreamingly in fortress-like field, or even a stage, which distributes from the inner arena to its external battlement, to its border of rubbish and swamp, two opposed battle fields where the subject entangles himself seeking for the highest and furthest inner castle, whose form [...] symbolizes the es in a surprising way. [...]. We see accomplished such structures of fortified work whose metaphor suggests spontaneously, as if it had come out of the very symptoms of the subject to convey the mechanisms of reversal, isolation, double, annulment and displacement of the obsessive neurosis.' (p. 101).
}

recognises somebody else's presence, like the father's, it immediately feels this paternal interference as a 'primordial hatred', as Lacan and Freud defined it, causing the baby to be individuated, constituting the moment of individuation.

Lacan introduces the bi-dimensional mirror in our image before the oedipal stage. It offers the unified image, which is so important due to the child's lack of notion of bodily integrity, which is different to the other mammals. This notion complements metonimically the bodily totality of not being unified. ${ }^{2}$ It is menaced by the other's presence and its consequent resentment of being menaced is unleashed. Thus, this non-existent subject projects itself into the other. The recognition of the other is shown as negation, the other is negated as if saying 'he is not me'; by negating that other thing, the baby tries to occupy the place of the other. When the third element is recognised, then something like symbolic identification is projected as rivalry. Thus, the first mirror stage is an idealisation and negation of the other, because the other has to be eliminated, which leads to hatred, madness, and late mimetic hostility. According to Lacan, 'this moment when the mirror stage is constituted, it inaugurates, by the identification with the imago of the other and by the primordial drama of jealousy $[\ldots]$, the dialectics which since then links the $[I]$ to the socially elaborated situations.' (Lacan, 1998, p. 101). The recognition of the presence of the father leads to the consequent recognition of selfness and the other. As Lacan points out,

\footnotetext{
2 'In order to locate it in the mirror stage, let us know first how to read there the paradigm of the very imaginary definition which comes from metonymy: the part by the whole. For we do not omit what our concept involves in the analytic experience of fantasy, those images above-mentioned as partial, the only to deserve the reference of a primeval archaism, which we named as images of the lacerate body, and which are configured by the assertion of the fantasies of the so-called paranoid phase in Klein's phenomenology of experience.' (p. 74)
} 
This development is experienced as a temporal dialectics which projects decisively in history the individual's formation: the mirror stage is a drama whose inner impulse precipitates itself from the insufficiency to an anticipation - and which makes to the subject, got in this allurement of spatial identification, the fantasies which happen since a lacerate image of the body until a form of totality [...] and for the armour finally taken upon himself of an alienated identity, which will mark in its rigid structure all his mental development. Thus, the split of the circle of the Innenwelt to the Umwelt generates the inexhaustible quadrature of the inventorying of the I (LACAN, 1998, p. 100).

From the image of this "lacerate body" the foetus can just develop itself being identified with the other, or it can re-stage, over and over again, compulsively this primordial process of phagocytises in every image it sees which reminds it of the imago incrusted in its own self. The symbolic identification creates a set of imagos and signifier which constitutes the inner self.

However, since I have been working with literature, I should not just start from this human psychoanalytical assumption in Lacan's theory, although I think it helps in defining inwardness very much . From the idea of the mirror stage, in which the self creates its first identifications and imago, Lacan exploits the signifier which is constituting of the self. And for that, let us take a look in his essay on the Purloined Letter.

Lacan starts the Seminar on the Purloined Letter remembering the Freudian 'automatism of repetition' (Wiederholungszwang), which extracts its principle from what has been called by Lacan the insistence on the signifier chain. For Lacan, the symbolic order is 'constitutive to the subject, demonstrating it in a history the fundamental determination which the subject receives from the route of a signifier.' (Lacan, 1998, p. 14). In that sense, he points out, in Poe's short-story, a rest, which remains in the air, in the atmosphere, which could be called the symbolic signifier of the letter. The signifier of the letter passes through different points of view in the story: the Queen's, the Minister's, the policemen's, and finally Dupin's. Thus the automatism of repetition is done by the inter-subjective mode in the story, which is the driving of the signifier through their eyes, their intersubjective repetition. (Lacan, 1998, p. 18). The nonverbal communication, i. e., the same gestures determines the domain which the discourse repeats and the symptom is repeated. As Lacan points out, 'the indirect language decants the dimension of the language.' (Lacan, 1998, p. 21). Once the thing is pronounced - the letter - it hovers the story and haunts its characters, it is repeated throughout it. It works as a leitmotif in the story. In that sense he states that

The signifier is the unity by being unique, not being, by nature, but the symbol of an absence. And it is for that we cannot say of the purloined letter [de la lettre, in French] which, similarly to other objects, it must be or not be somewhere, yet, different from them, it will be and will not be where it be, where it goes (LACAN, 1998, p. 27).

Lacan highlights not just the presence of the letter, but the meaning which can deeply harm the Queen's reputation and honour. Once it could be mentioned in the story, it hovers everywhere and nowhere, unleashing all possible determinations of what the characters do in their lives. According to Lacan,

The replacement of the signifier determines the subjects in their acts, their destiny, their refusals, their blindness, their successes and their luck, although their inborn gifts and their social position, without taking into account the character or the sex, and which, for good or for evil, will follow the route of the signifier, like guns and luggage, everything which is the origin from the psychological datum (LACAN, 1998, p. 33-34) 
Lacan also remarks that once the letter is not protested, 'as they pass by its shadow, they turn out to be their reflection. As they possess the letter [...] is its meaning which possesses them.' (Lacan, 1998, p. 34). Thus, the signifier is not constituted by the subject, but on the contrary, it is exactly the signifier which constitutes the subject. Nevertheless, the subject does not see his constitution in the signifier, he just denies it. Thus, blindness turns out to be the concealing element of subjectivity, which just someone as an analyst can show it. As Lacan points out 'Dupin turns to us the face of Medusa of that signifier from which nobody, unless the Queen, could read the reverse'. (Lacan, 1998, p. 44). Dupin plays the role of a sort of psychoanalyst in the story, in the way that he shows exactly what nobody wants to see. Therefore, blindness is a key-word for interpreting and seeing what the unconscious does not let reveal. According to Lacan, 'we see the audacious reduced to the condition of feeble-minded blindness in which he plunges the man before the letters of battlement which dictate his destiny.' Here we can see a keyword in the short-story and in psychoanalytical method: blindness, i. e., the letter was left exactly where nobody thought it was. It is there where we have to look for. In a certain sense, Saramago's novel Blindness emphasizes Lacan's assumptions that what we see is not really the truth, but only a fake and distorted image of the real. According to Costa (2015), 'the novel deconstructs the occidental privilege given to vision, exposing the fallibility of truth as a guiding principle to human existence.' (2015, p. 24). It is in an unimaginable place, where we have to search for the truth. It is in front of our face, it is presented everywhere and nowhere.

As Lacan points out, Dupin's strategy 'was already contained and was easy to be deduced in the title of the tale, according to the very formula, which we have very long submitted to his appreciation, the formula of the intersubjective communication, in which the emissor, as we have said, receives from the receptor its own message in an inverted form'. (Lacan, 1998, p. 45, highlights added). It is as if when a word is uttered by a character, this word is spread out in all places of the story or the play, constituting then the very signifier which is reproduced in many levels, which we can see in the silences, in the nonsaid, and in the non-sequiturs. In King Lear when Gloucester talks about his wife, Edmund's mother, the absent presence of the symbolic figure of a mother hovers over the play, incrusted in its constellations. It constitutes the play as if this motif were fundamentally and psychically incrusted both in the atmosphere of the play and in the subjective and inter-subjective dimensions of the character; or else, it is an over-determining element of the play, which will be reproduced in Cordelia's absence in the play.

\section{Gloucester and Edmond: Shame and anxiety}

The play King Lear starts with the revelation of the division of the Kingdom. Kent and Gloucester discusses very briefly that fact. It is worth noticing the speed of their conversation:

KENT. I thought the king had more affected the Duke of Albany than Cornwall.

GLOUCESTER. It did always seem so to us: but now, in the division of the kingdom, it appears not which of the dukes he values most; for equalities are so weighed, that curiosity in neither can make choice of either's moiety (SHAKESPEARE, 1987, p. 1).

The first thing we know is that King Lear decided to divide the kingdom. However, this first conversation reveals something more underneath the discourse. Derek Cohen, in his book Searching Shakespeare (2003), points out that both Kent and Gloucester mistook Lear's relationship towards the Dukes of Albany and Cornwall. Nevertheless, I think Kent and Gloucester's dialogue may suggest Lear's 
trouble-making disposition and inconstant humour. The words equalities and moiety reveals through a mathematical formula that the affections, feelings and love are measured by mechanical and cold means which will be recurrent in King Lear. Furthermore, we may deduce through the revelation - 'I thought the king had more affected the Duke of Albany than Cornwall' - that the Duke of Cornwall might have flattered Lear in order to re-conquer the king's affections, in the same way as both Goneril and Regan will do very soon, considering the mirroring device in the play. Thus, if both Kent and Gloucester have thought that these were some inequalities, the change of that situation may be due to Cornwall's flattering Lear.

Another weird detail is that both Kent and Gloucester talk about the division of the kingdom very briefly, as if someone could hear their conversation. Once the division of the kingdom is actually bad news to the whole kingdom, the announcement would certainly not be very welcomed by Lear's subjects, because no king would do that in the Renaissance Age. In fact, King James I's intention was just right the opposite: uniting and keeping the kingdom of England, Scotland and Ireland together. ${ }^{3}$ For Laurie Maguire (2004), in her book Studying Shakespeare, the Renaissance audience, when watching a scene presenting the division of a Kingdom would immediately take it very seriously. Another example can be taken in 1 Henry IV: even though the comic division of the kingdom was 'full of exaggeratedly comic incompetence' (2004, p. 41), the audience would take this seriously. In both plays, Henry IV and King Lear, 'it is impossible to imagine a sixteenth-century audience not taking it seriously given that the

\footnotetext{
${ }^{3}$ Park Honan in his biography Shakespeare (2001) suggests that King Lear plays the in the counter-current of Jamesian politics, which was to keep the three kingdoms together.
}

memory of civil war was so recent. For a king to initiate territorial division would be even more alarming' (2004, p. 41). Thus, the audience would immediately feel that there was something problematic and gloomy about Lear's decision.

Consequently, there is a quick change of subject in the conversation about the division of the kingdom to Edmund's origins. It seems that they cannot speak loudly and long about that fact, since somebody might be eavesdropping their conversation. Its quick duration and its interruption hint the silence these noblemen must keep. I also believe in another possibility: that the eavesdropper in this scene could be Edmund due to his troublemaking dispositions, as we come to learn in the second scene of the play. The scene-heading is clear: 'Enter KENT, GLOUCESTER, and EDMUND'. Thus, it hints that Edmund's hearing could be problematic, once he could take advantage of the situation. However, both Kent and Gloucester might not have acknowledged this at first, even though unconsciously they feel and foresee that somebody could hear them.

It is also strange that Kent and Gloucester speak in prose not in verse, which suggests in the language the low importance given to the subject of the division of the kingdom. Moreover, the slight cut of the topic is much more concealed by the prose than it would be perceived in verse, as we can see in Macbeth, for instance, in which the silences are presented in the cut of the hemistich of the verse. ${ }^{4}$ In

\footnotetext{
${ }^{4}$ In Macbeth we can see these silences very clearly. When the couple Macbeth discusses Duncan's coming, Lady Macbeth suggests in the silence:
}

MACBETH. My dearest love,

Duncan comes here to-night.

LADY MACBETH. And when goes hence?

MACBETH. To-morrow, as he purposes.

LADY MACBETH. O, never

Shall sun that morrow see!

Your face, my thane, is as a book where men

May read strange matters. 
this case, the prose works to conceal the silence which would be much more visible in the verse. Therefore, I think Shakespeare intertwined at this point such weird possibilities in order to create strange and sinister tones in the play. These ones work simultaneously to build up the aesthetic artistry of the play, so that the audience cannot identify exactly what is going on in the first place, yet they can feel something strange, gloomy and even catastrophic.

As they change abruptly the issue of the division of the kingdom, Kent asks whether Edmund is not Gloucester's son. Gloucester reveals his deep discontent about the supposed betrayal of his wife: 'His breeding, sir, hath been at my charge: I have / so often blushed to acknowledge him, that now I am brazed to it." (Shakespeare, 1987, p. 2). The text suggests in the words blushed and brazed a sort of tacit involvement pointing to moral feelings such as shame. We have to remember that brazed signals 'metal alloy, tinker, solder, dress up', but also 'covering and ornament'. Gloucester feels, on the one hand, shame for Edmund; nevertheless, in a second level, brazed means ornamented, which might suggest his desire to be involved in this sinister fact, which slightly reveals something subjacent in his psyche, the silenced desire of being involved in such a relation. As Northrop Frye suggests (On Shakespeare, 1986), Gloucester ambiguously feels himself proud of Edmund. The ambiguity of his words might allude to the unconscious desire to be involved and deeply joint in that possible betrayal, in a perverse relationship, or an unconscious need of an intimate link with the offspring who is the son of his wife, the son of her fault. Therefore, his stain may

The verse 'Shall sun that morrow see!' is cut in the middle so that the reader and the audience can imagine them looking each other and thinking something like: 'We'll do the deed tonight". The actress may represent this act by being silent for a few seconds. symbolically re-stage the individuating moment of the self, evoking unconsciously the maculated desire of being fused with the maternal figure.

In a similar way, Stanley Cavell has written a very interesting essay on King Lear, named The Avoidance of Love, in his book Must we mean what we say? (2005). According to him, Shakespeare's play, which conveys a strong sense of isolation and despair, works on the problematic issue of recognition, i. e., self-recognition. When the words 'eyes', 'see' and 'look' are used in the play, they do not convey 'moral insight' (2005, p. 273), but they literally convey common uses of eyes: to 'feel', 'weep' and 'recognise' others. Both Lear and Gloucester do not want to acknowledge something which would be naturally accepted and desired: the latter avoids shame and the former love. According to him,

I do not wish to suggest that 'avoidance of love' and 'avoidance of a particular kind of love' are alternative hypotheses about this play. On the contrary, they seem to me to interpret one another. Avoidance of love is always, or always begins as, an avoidance of a particular kind of love: men do not just naturally not love, they learn not to. And our lives begin by having to accept under the name of love whatever closeness is offered, and by then having to forgo its object. And the avoidance of a particular kind of love, or the acceptance or rejection, is mirrored in every other. It is part of the miracle of the vision in King Lear to bring this before us, so that we do not care whether the kind of love felt between these two is forbidden according to man's lights. We care whether love is or is not altogether forbidden to man, whether we may not altogether be incapable of it, of admitting it into our world. We wonder whether we may always go mad between the equal efforts and terrors at once of rejecting and of accepting love. The soul torn between them, the body feels torn [...] and the solution to this insoluble condition is to wish for the tearing apart of the world (CAVELL, 2005, p. 300).

Both Gloucester's and Lear's shame and avoidance of love are due to the lack of selfrecognition. Cavell points out that the failure of 
recognising others is the failure of letting recognise oneself, 'a fear of what is revealed to them, an avoidance of their eyes' (2005, p. 277), the cause of such an avoidance is shame. Cavell (2005, p. 277-8) enhances that

shame is the discomfort produced by the sense of being looked at, the avoidance of the sight of others is the reflex it produces. Guilt is different; there the reflex is to avoid discovery. [...] Under shame, what must be covered up is not your deed, but yourself. It is a more primitive emotion than guilt, as inescapable as the possession of a body, the first object of shame. Gloucester suffers the same punishment he inflicts: in his respectability, he avoided eyes; when respectability falls away and the disreputable come into power, his eyes are avoided.

In that sense, Gloucester unconsciously revealed his shame as he says 'braz'd to it', i. e., he admits that 'he has fathered a bastard, and also perhaps carrying the original sense of soldered fast to it.' (2005, p. 276). He utters this sort of feeling when he says twice that he 'acknowledges' he has a son who is a bastard. Nevertheless, according to Cavell (2005, p. 276),

\begin{abstract}
He does not acknowledge him, as a son or a person, with his feelings of illegitimacy and being cast out. That is something Gloucester ought to be ashamed of; his shame is itself more shameful that his one piece of licentiousness. This is one of the inconveniences of shame, that it is generally inaccurate, attaches to the wrong thing.
\end{abstract}

Cavell points out that Gloucester jokes about himself. Such an attitude is very common and specific for 'brazening out shame', i. e., drawing attention to what somebody does not want to notice in a natural way. (2005, p. 277). We must remember Freud's essay Wit and its relation to the Unconscious (1905; 2006). Joking is something commonly related to hidden desires which do not want to acknowledge. Furthermore, joking and wit come out in speeches as a form of aggression, confrontation, disdain and violence.

Moreover, the character Edmund functions as an absent member in the play. This influence is going to pervade many characters' inwardness. According to Cavell, he echoes mainly in Lear's mind in the heath scene, when the king stands up for bastards, 'an illegitimate King in an unlawful world.' (2005, p. 308). In that sense, Lear and Edmund, and I think Gloucester as well, evoke sexual disgust. Cavell states that 'Lear's disgust with sexual nature is not far from Edmund's early manic praise of it, especially in their joint sense of the world as alive in its pursuit.' (2005, p. 308). Lear and Edmund have similar attitudes, either it be positive or negative towards sexual relationship.

Similarly, Laurie Maguire (2004), states that 'Edmund is present, but Gloucester insensitively talks about him as if he were not, indulging in cavalier sexual allusion' (2004, p. 185), exactly when he says 'though this knave came something saucily into the world before he was sent for, yet was his mother fair; there was good sport at his making, and the whoreson must be acknowledged.' (I, i, 21-24). Gloucester both jokes and feels shame of his bastard, which shows his ambiguity of feelings towards sexual affaires. Thus, for Maguire, the audience sympathises with Edmund and 'feels critical of the insensitive Gloucester.' ( $p$. 185).

Furthermore, Gloucester's awkward revelation about Edmund signals the anxiety of having been betrayed in the maternal absence, played out in a sort of Fort-Da fantasy; such an undesired absence eliminates, through the primeval scission, the exclusivity and the maternal fusion in his pre-oedipal relation with his mother figure, awakening the unconscious anxiety of castration in an indefinite past. That anxiety is suggested when he describes Edmund's mother, employing images of the 
prodigious and suffocating growth. In his conversation with Kent, just after having described his brazed alloy with Edmund, he says:

KENT. I cannot conceive you.

GLOUCESTER. Sir, this young fellow's mother could: whereupon she grew round-wombed, and had, indeed, sir, a son for her cradle ere she had a husband for her bed. Do you smell a fault? (SHAKESPEARE, 1987, p. 2)

Kent cannot understand Gloucester's brazed relation with Edmund; nevertheless he employs the pun conceive in the meaning of both conceive and understand. Adelman (1992) suggests that Edmund's mother is just mentioned by her absence. For the author, the pun with conceive deals with the tenuity of the paternal biological relation. For Adelman, Kent cannot understand what Gloucester wants to say in the very beginning, because he is so evasive, which suggests that the paternal figure's function is undermined, representing in that pun the evasive function of male reproduction. (Adelman, 1992, p. 106). However, I think Gloucester does not utter the word conceive at first, but he employs it implicitly, by replacing it with the verb could, which syntactically signals to something hidden and occluded in this statement, maybe an occluded and concealed desire in his affective relationship to her. Conceive alludes to Gloucester's sexual fantasies that conceive/understand such an unconscious alloy and sinister relation is only possible in an ultimate close uterine-like ligation. Such desire refers to Gloucester's primeval and pre-oedipal phase with the maternal body, which is occluded syntactically, but is semantically reinforced. Adelman takes that pun to reinforce the split biological relation of father and son, that is to say, Edmund is not his father's son, only his mother's fault. (Adelman, 1992, p. 105). Nevertheless, as we have seen above, their relation is unconsciously deeper and much more intimate, as a hard, metal alloy, which is suggested in the pun brazed, meaning ornamented, beautiful, even seductive to the eyes and to the other senses, therefore, desired. Thus, what Gloucester suggests with the puns conceive and brazed allude to the innermost league with the maternal body in the preoedipal phase, which unleashes feelings of fear in the individuating moment, re-imagined in his relation to his bastard son. As we can see, Shakespeare introduces this sort of ambiguous puns in order to create an aesthetic device and to reveal through them Gloucester's innermost feelings and inwardness. Language is a framework to understand and figure out inwardness in Shakespeare's tragedy. Inwardness is constituted by both the unconscious meaningful use of language and by the lack language, i. e., the silences, the non-said and the non-sequitur, which suggest innermost concealed feelings.

Besides that, Gloucester gives another hint by asking Kent 'Do you smell a fault?' The reference to smell, one of the most primitive senses, used by animals as a means of finding the prey, certainly refers to the sensation of the fault and the maternal body which is felt as something ambiguously disgusting and desirable to Gloucester. If this slightly hints Gloucester's innermost primeval disgusting repulsion, this same reference can unconsciously suggest the contrary, according to the Freudian framework of what is negative conceals hidden positive feelings. There is an ambiguous tone of shame explicit in the depreciatory terms, as well as a moralist tone, which conversely reveals pride in being involved in that relationship, illicit to him. By being involved in such relationship evokes in the first level a negative and disgusting feeling, which, on the other hand, may allude to positive feelings occluded and obfuscated in his inwardness. Additionally, that is exactly the very tone he uses to talk proudly about his son Edgar: 
But I have, sir, a son by order of law, some year elder than this, who yet is no dearer in my account: though this knave came something saucily into the world before he was sent for, yet was his mother fair; there was good sport at his making, and the whoreson must be acknowledged (SHAKESPEARE, 1987, p. 3)

It is interesting to notice that both Edmund and Edgar are unique children who have a mother in King Lear. Edmund is literally only his mother's son, whereas Gloucester's other son, Edgar, is his father's son, the son of the law, the son of the paternal lineage. We know so few about Edgar from his father's mouth: just that he is 'son by order of law'. Most strikingly, Gloucester talks about his son Edgar just two verses and then he draws his attentions to Edmund again. If there is any kind of resentment, hatred, puritan shame nourished by Gloucester, it would signal once again in Freudian framework that unconsciously there is a positive occulted desire; shame is the negative element in Gloucester's statement, whereas his insistence in talking about Edmund signs something obscure and ambivalent in his relation with him, a sinister disposition which always attracts and draws his attention back to the maternal body, the body of the fault, re-imagined in his brazed relation with his son and conceived with the round-wombed body of his mistress.

\section{Gloucester's Inwardness and Anxieties regarding}

\section{the Maternal Figure}

Janet Adelman (1992) analyses maternal fantasies of Shakespearean male characters, whose fantasies are re-imagined as a return to the maternal body. Adelman points out, in that sense, that 'this transmission from father to son can take place only insofar as both father and son pass through the body of a woman; and this passage radically alters them both.' 'Maternal origin and illegitimacy are synonymous in Lear'. (1992, p. 107). According to her, the locus of the mother, considered as sinister, contaminates the son, 'jeopardizing the presence of the father in him'. This re-imagined return is disclosed in terms of aggression and confrontation with the maternal body, because the female body is in general seen as a locus of evil, danger and death for the male child. According to her, 'the actual conditions of infancy would have intersected with cultural representations of the female body to mark that body as the site of deformation and vulnerability' (1992, p. 05).

In a period of starvation, when children routinely died, mothers were held as responsible for those deaths (Adelman, 1992, p. 04). Since the maternal milk was considered dangerous, even noxious to the child, and pus, wet-nursing was sometimes regarded as the cause of many children's deaths (1992, p. 06). That long period of starvation created a long dependency on the maternal body, during which children were said to be subjected not only to dangers, but mainly to psychological dependency on the mother. The author states that 'the womb was traditionally understood as the entrance to death and the site of mortality' (1992, p. 06). Thus, negative views on women were normally conveyed by many analogies, which represented them tendentiously and negatively.

Moreover, wet-nursing was re-imagined by male children as abandonment. Reports from diaries and letters show that little boys imagined they had been abandoned twice: first by the mother, who gave him to a nurse, and then again by the nurse, who gave him back to his mother. Adelman states that,

Wet-nursing merely gave the child two psychic sites of intense maternal deprivation rather than one: first, the original maternal rejection signaled by wet-nursing itself; and then the weaning - routinely by the application of wormwood or another bitter-tasting substance to 
the nipple - and abrupt separation form the nurse-mother he or she might have known for two or three years (ADELMAN, 1992, p. 05).

These actual social conditions created thus a negative perceiving about wet-nursing as something noxious and dangerous to children. However, that had not only been the main cause: the Aristotelian theory in his Genesis states the duality between male and female as a duality 'linking male with spirit or form and the female with matter, as though mortality itself were the sign of hereditary deformation by the male' (Adelman, 1992, p. 06). Both social conditions and beliefs, as the belief that the maternal first milk was noxious, led to negative projections of the 'child's vulnerability in the body of the mother/nurse' (1992, p. 06). As one can see, social nourishing and medical birth problems created depreciatory projections on women, as though these events were something natural and were consequently taken for granted.

Those distorted ideas will be projected by the Renaissance playwrights and poets as well, such as Sidney, Spencer, and Shakespeare. For instance, in Richard III by Shakespeare, Richard's fantasy that his mother's womb had deformed his body reiterates symbolically that the mother "could literally deform foetuses through excessive imagination, her uncontrolled longings, her unnatural lusts. His fantasy of suffocation in the womb is no more than scientific fact: many understood birth itself as the foetus's response to the inadequate supply of air of food in the womb'. (Adelman, 1992, p. 06). This negative view is not only projected in terms of dramatic devices in Shakespeare's plays, but also as a social construct rebuilt in his plays, based on $16^{\text {th }}$ and $17^{\text {th }}$ century's medical, moral, and theological discourses.

Moreover, even spontaneous abortion or miscarriage was scientifically held as the mother's responsibility, because of excessive blood, food, or even suffocation and strangulation in the mother's belly (Adelman, 1992, p. 06). At this point, we can perceive, both in Shakespeare and in social discourses, male inward projections towards the female body due, in fact, not to actual biological and natural women conditions, but to beliefs, medical and moral discourses which preached and evaluated negatively mothers' conditions, as something natural and willing.

The negation of the mother and wife is not only revealed in her absence, but also in the negation of her son. For example, one of the strangest details about Gloucester plot is that, only now, Edmund is presented to Kent, such an important nobleman in Lear's court. It is quite improbable that Kent could not know Edmund even when he was a child. Bernard Lott suggests, in a note in his edition to King Lear, that this fact reveals Edmund's evil and troublemaking character. However, I think that Gloucester's intention is to hide his son from the court, keeping away and occulted his undesired issue, which could potentially disturb his pre-oedipal fantasies, as he says before Lear's entering the scene: 'He hath been out nine years, and away he shall again.' (Shakespeare, 1987, p. 3). I think that this could suggest Edmund's evil character, but it signs, above all, that the engendering nucleus of his hatred and his trouble-making dispositions, nourished to his father and brother Edgar, can originally be rooted in his father's negation and shame of him. Nevertheless, Gloucester's ligation to Edmund - as he suggests with the pun brazed - reveals, on the one hand, sinister and ambivalent dispositions of his desire of betrayal, which he does not want to see and acknowledge, once it is occulted; on the other hand, it is constantly evoked in the figure of the son and proudly remembered by Gloucester himself. His son's removal from the mother can sign the desire of exclusivity of her presence and possession of the 
wife, since Edmund's presence could bring up, every now and then, that he had had a son out of their marriage. Therefore, his desire of possession and his proud could be constantly stained by the presence of his son. In the same sense, the lack of love is obviously related to the loss of the primeval unity. This new space of inwardness hides unconscious desires and affective anxieties, revealed through the gesture of keeping away Gloucester's son from the mother's presence and in the non-said suggested in brazed and conceive. The natural fear for lack of love is projected in the wife's figure, whose analogy round-wombed rebinds the pre-oedipal alloy in the mistress figure. Edmund's presence could remind him of something related to his possession and jealousy to the maternal figure. Thus, the absence of both mother and son must be imposed in order to create a locus of fused and exclusive unity with the idealised imago.

Obviously the non-revealed jealousy at this point, only suggested when Gloucester imputes Edmund's conception only to his mistress, signals one more trait of anxiety due the loss of the exclusivity to the imago, as the idealised locus and the element of concretisation of totality and preoedipal unity. Edmund's jealousy of his brother suggests the reader that such a disturbing feeling can happen not only to the son, as well as to the paternal figure, as a pattern of behaviour acquired and repeated in some moment in a person's childhood, as Freud had suggested Contributions to the Psychology of Love (2006) We can see how Shakespeare cunningly signs only in the gestures and in the silences of the play the unconscious psychic structures of the self's inwardness, veiled to the characters, which nonetheless come out in the language and in the silences. It is striking Shakespeare's amazing clairvoyance in perceiving and creating symbolically, four centuries before the emergence of psychoanalysis, the occulted connections between fantasies of the pre-oedipal phase of the psyche and the self's inwardness only in metaphors, puns, silences, driving and evasive suggestions. ${ }^{5}$ Those unconscious relations between pre-oedipal fantasies and the presence/absence of the maternal figure - re-imagined in his wife's betrayal and in the insistence of this fact - reveal in it a sort of psychic leitmotiv which will echo throughout the play either in the characters' images and gestures, or in the silences of the characters' anxieties.

Furthermore, this set of constellations will be over-determining to Lear plot. Gloucester plot is an over-determining plot in Lear plot. Everything which happens in Gloucester plot is duplicated in Lear's one. For instance, the ambiguous details in the first lines of the play suggest a sinister atmosphere in it and a sort of discontent which hovers in the relations between fathers and children means that there is something wrong in their relations. The gloominess of the play is elucidated in the opening conversion between Kent and Gloucester about his sons. This scene suggests what Freud would call an overdetermining plot or correlate in the play. In its very beginning, both plots - Gloucester plot and Lear plot - seem to be unmatched and uncorrelated. Nevertheless, as the action moves on we perceive that both are very intrinsic. What happens in one plot is quite reproduced, sometimes in a different way in the other plot, intermingling the characters' identities. In the same sense Cavell (2005, p. 280) points out that,

Gloucester has by now become not just a figure
'parallel' to Lear, but Lear's double; he does not
merely represent Lear, but is physically identical
with him. [...] In this fusion of plots and
identities, we have the great image, the double
or mirror image, of everyman who has gone to
every length to avoid himself, caught at the
moment of coming upon himself face to face.

${ }^{5}$ Stephen Greenblatt has already suggested that Shakespeare was the inventor of the psychoanalysis, in his text Renaissance Culture and Psychoanalysis. Standford: Standford UP, 1984. 
Gloucester's concern with his bastard and true son suggests what Lear does in the same scene with Cordelia: desinheriting her and making her an outcast, as Edmund was. Gloucester's blindness will be a symbolic sign of Lear's blindness about his daughter. The constellations in Gloucester's plot is reproduced in Lear's one, in such a way that the aesthetic effect is too impacting and even too intimate to us.

If Gloucester, on the one hand, ambiguously nourishes shame, shyness and hatred towards Edmund, on the other hand, he unconsciously draws symbolically and fantasmatically his attentions to the fault of the scission of the primeval stage, the scene of the individuation and his sinister desire for betrayal; such an ambiguous relation between father/mother $\mathrm{x}$ son/wife re-stages his ambivalent relation to the maternal body. Consequently, it signals the presence of something sinister as an overdetermining motive of the play: the presence/absence of the mothers in King Lear works as a signifier which leads and constitutes the characters' inwardness, which is build up in absence of both maternal presence and lack of love, as Cavell pointed out. Although Gloucester repels his relation and fatherhood to this son, as he utters Do you smell the fault?, unconsciously he draws his attentions and concerns to the primeval fantasies and anxieties projected on the maternal imago implicitly reminded in the ambiguous relation with both Edmund and his wife.

Therefore, the hidden suggestions given by the words brazed, fault, smell, conceive are a sort of signifiers and over-determining motive which hover in the play, contaminating every sphere, i. e., characters, discourses, puns, silences. It leads to something related to the pre-oedipal phase, reimagined in these signifiers, metaphors, and images.
Shakespeare very cunningly uses this set of symbolic motives suggested in the language of the play in order to create its aesthetic effects, as well as to reveal the concealed inwardness of the characters. Therefore, if Gloucester's relation with his son and wife suggests his sinister dispositions which hover in the play and contaminate its imagery, we will also see something similar in Lear's relation with his daughters, which is over-determined by Gloucester's initial mention to his sons.

\section{FINAL REMARKS}

In that sense, one might see Lear's and Gloucester's blindness in not recognising his own failure and limits. When he refuses to accept Cordelia's nothing as the only thing she can say, not because she does not love him, but because she cannot heave her heart to her mouth, saying false words as her sisters do, Lear fails in not recognising individuation and avoidance of love: he just wants to annihilate his daughthers as objects which must idolise and flatter him. Lear's and Gloucester's first words unleash something which will hover the play as a whole, as the signifier which defines the subjects and their inwardness.

That is exactly what I will propose in my analysis. I shall start from very unique elements unperceived by some critics. As we will see, in Lear, when he says - 'the shadowy forests' and 'my darker porpuse'- he introduces the signifier, which will be present in the play. The signifier in King Lear 'our darker purpose' and 'shadowy forests' functions as symbolic signs which evoke dark dimensions which lead to something hidden of the self. Cordelia's absence is another case: she disappears and thereby Lear plays out a sort of Fort-Da fantasy: Shakespeare hides her in the play in order to create through her absence the symbolic fundamental signifier of the play, the absence of the mother figure, re-imagined in 
Cordelia. ${ }^{6}$ Through these signifiers we can see what is hidden in the play, what is suggestive and emanates as a core meaning of the characters' inwardness. They sign to all constellations of images in the plays.

When Lear utters "the shadowy forests" he is referring to something unconsciously incrusted in the psychic structure of the self, in his inwardness. However, this reference is not only characteristic of his own self, but it hovers over the play and haunts, threatens and conceals the edges of individuation. In that sense, what Lacan defines as subjectivity is very important for this analysis: 'The subjectivity, in its origin, is of no relation with the real, but of a syntax engendered in it by the mark of the signifier.' (Lacan, 1998, p. 55). That is to say, the absence marks and unleashes the construction of the self through the signifier of that syntax. It is in the absence of the projected idealised image which the subject thinks, through an alluring game, to be its own image. In the instant of the individuation, the splitting moment from the maternal body, the signifier marks the absence and defines the individuation of the subject and, therefore, his own inwardness.

Todos os autores declararam não haver qualquer potencial conflito de interesses referente a este artigo.

\section{REFERÊNCIAS}

ADELMAN, Janet. Suffocating Mothers: fantasies of maternal origin in Shakespeare's plays, Hamlet to Tempest. New York: Routledge, 1992.

CAVELL, S. The avoidance of love. In: Must we mean what we say?. London: CUP, 2005.

COHEN, Derek. Searching Shakespeare: Studies in Culture and Authority. Toronto: University of Toronto Press, 2003.

\footnotetext{
${ }^{6}$ And also Shylock's case, his presence and defeat in the play signs the disturbing feeling which is shown by being sad, weary/aweary and unhappy in the very beginning of play. His very bond of the letter - a pound of flesh in three months - is the symbolic signifier which will hover throughout the play interfering in Antonio's and Bassanio's inwardness, in Shakespeare's Merchant of Venice (1960).
}

COSTA, André Vinicius Lira. Visão e verdade.

Porto das Letras, vol. 1, n. 1, p. 24 - 35, mar. 2015. ISSN 2448-0819. Disponível em:

https://sistemas2.uft.edu.br:8004/index.php/portodasl etras/article/view/1881. Acesso em: 18 ago. 2016.

FREUD, Sigmund. Edição Standard Brasileira das Obras psicológicas Completas de Sigmund Freud. Rio de Janeiro: Imago, 2006.

FRYE, Northrop. On Shakespeare. London: Penguin, 1986.

GREENBLATT, Stephen. Renaissance Culture and Psychoanalysis. Standford: Standford UP, 1984.

LACAN, J.. Escritos. Rio de Janeiro: Jorge Zahar, 1998.

MAUS, Katharine Eisaman. Inwardness and Theater in the English Renaissance. Chicago e London: University of Chicago Press, 1995.

MAGUIRE, Laurie E. Studying Shakespeare: A Guide to the Plays. Oxford: Blackwell Publishing, 2004.

SARAMAGO, J. Blindness. London: Penguin, 2011.

SHAKESPEARE, William King Lear. Edited by Bernard Lott. Essex: Longman, 1987.

SHAKESPEARE. Macbeth. Edited by Kenneth Muir. Londres: Arden, 1997.

SHAKESPEARE. The Merchant of Venice. Londres: Heinemann, 1960.

SMITH, Lacey Baldwin. Treason in Tudor England: Politics and Paranoia. London: Pimlico, 2006. 